\title{
VILLAGE INNOVATION THROUGH VILLAGE INFORMATION ADMINISTRATION SYSTEM (SAID) IN BONDOWOSO DISTRICT EAST JAVA PROVINCE
}

\author{
Nian Riawati., MPA \\ Faculty of Politic and Social Science, University of Jember, \\ nian.fisip@unej.ac.id
}

\begin{abstract}
The Evaluation of Pilot Project Universitas Membangun Desa (UMD) focuses on the development of villages in Bondowoso district of East Java province through the innovation of the use of information technology. This study presents an evaluation of the implementation of a pilot project of the Village Information Administration System (SAID) implemented in ten villages located in two wringin and cermee sub districts in 2016. This program is an innovative collaboration between Jember University, Community Collaboration and welfare services (KOMPAK) and Australian Aid. The purpose of this program is to build a Village Information System (SID) and utilize it to create an independent village in data and information, introduction of village potential and marketing of village superior products. through a qualitative approach, this research can describe the context and setting naturally through observation, interviews with stakeholders and beneficiaries of the program. The results show that the Village Information Administration System (SAID) is able to accelerate and improve the quality of village government services but there are several problems in its implementation such as internet network problems, low human resource competence, lack of support from village government and inadequate facilities and infrastructure.
\end{abstract}

Keywords: Village Information Administration System, Information Technology Innovation, Independent Village

\section{INTRODUCTIONS}

This paper discusses a pilot project of Universitas Membangun Desa (UMD) in Bondowoso District. This program is an innovative collaboration between Jember University, Community Collaboration and welfare services (KOMPAK) and Australian Aid. Through Innovation Program (Project-11) KOMPAK developed the UMD Program. Which aims to encourage innovative collaboration between KOMPAK and universities in Indonesia, to maximize the implementation of real work college program $(\mathrm{KKN})$ so as to have a systematic, significant and sustained impact on the poor in the village gain access to improved village governance. University of Jember, one of the winners of UMD program is innovating through information System Development and Integrated Information Service Center of village in Bondowoso District.

UMD was a pilot project conducted in ten villages in Bondowoso Distric. UMD Activities are the creation of SAID application, Village data updating and Village poverty data, as well as the initiation of the emergence of superior village product. Project Implementation took place in two stages, the first phase from February to March 2017, the second stage from july to August 2017. The first phase of the activity begins with the application of SAID in ten pilot village in Bondowoso District and excellent Product Initiation based on the local potential of the village. The second 
phase of data verification of the number of poor people with real village data for input in SAID data.

This paper present the findings of program evaluations, particularly those focused on the extent to which the UMD Program meets its stated objectives. Twostage study design has been completed (baseline and ex-post) and data were collected to measure program effectiveness and efficiency using qualitative methodologies. The use of qualitative methodologies presents an interesting and challenging issue for evaluators. The strength of this approach is to provide contextual and controversial understanding of emerging issues. Qualitative data help explain how and why the program achieved positive results. The disadvantage of this approach is that it is more difficult to generalize findings to other contexts. This paper describes how evaluation methodologies are developed and implemented and will provide contextual issues related to the UMD Program. In addition, this paper provides an important recommendation on the factors that influence the success of the program.

\section{Literatur Review}

The adoption of information technology by the government or often referred to as e-government at this time is a thing to do. E-government is defined as the use of computers and the Internet by government of information and communication technologies to deliver information and services to citizens, businesses, and other stakeholders (Nam, 2014).In this sense e-government has a meaning as the use of various means of information technology by the government in order penyampain information and the provision of services to the community, business and various parties concerned.Thus, e-government has two functions that the flow of information and the process of service.

Wang and Liao (2008) convey that many governments realize the importance of using information and communication technologies to provide efficient and transparent government. While Prybutok, Zhang, and Ryan (2008) provide a statement that the technology helps the government to improve services and assists in building trust between the government and businesses, and between government employees and the general public.

The adoption of information technology in government or the use of egovernment through SAID provides various benefits for the government in delivering services and delivering information to the public and how the government builds trust in the community. SAID helps the government in organizing government more effectively, efficiently, openly and responsibly to the public. SAID embodies independent villages in data and information so that villages have data on the number of poor people who will be the basis for the government in formulating poverty programs.

Yildiz (2007) says that E-government has emerged as a popular catchphrase in public administration to cover functional areas such as service delivery, interactivity, decentralization, transparency, and accountability. In addition, Larsson and Gronlund (2014) conveyed that technology plays a central part in the development of the public 
sector; it can act both as an enabler and as an obstacle to sustainability. In other respects, United Nation (2014) states that the implementation of e-government systems and appropriate applications require the acquisition of new skills from the government employees.

E-government as a breakthrough in governmental administration provides many advantages, but on the other hand the use of e-government in government also faces several obstacles, including the need for government employees to improve the ability of e-government management.As Anthopoulous et al (2015) found several causes of failure in the implementation of e-government

- overestimated the political will, created a major design-reality gap regarding the required performance against the potential number of users,

- this project was a large-scale one due to its budget and extremely complex because of its technical requirements and large number of stakeholders, while the overall planning and management did not focus on these characteristics (i.e., day-to-day effective project micro-management, initially defined extended timeframe, and so forth);

- shifting requirements for system's performance and developers' skills resulted in project scope's changes; and

- failures in budget and time control illustrate that an inappropriate and inefficient project management methodology was followed.

Various factors overshadow the implementation of e-government, be it from the political aspect, financial aspects, to the failure in shooting the ability of the apparatus in managing e-government.However, in the implementation of egovernment DeLone and McLean (2003) provide a model of successful implementation of e-government that is influenced by information quality factors, system quality, service quality, usage intensity and user satisfaction. The following are the egovernment models of DeLone and McLean (2003)

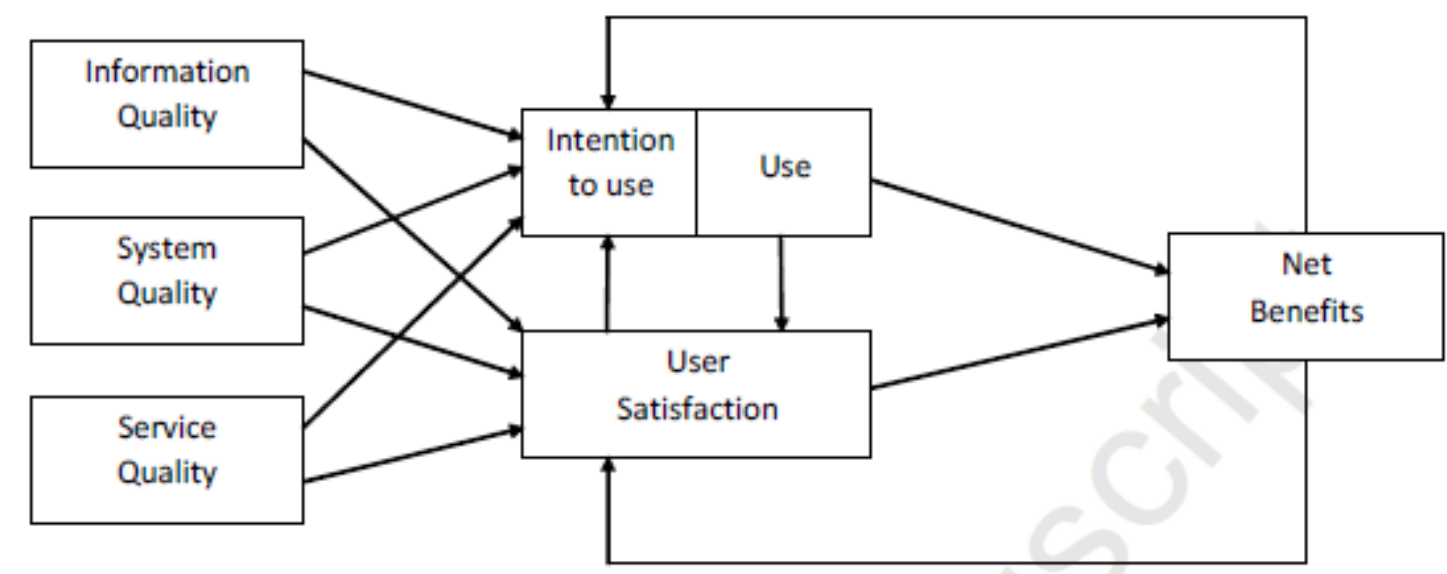

Figure 1. Model of Successful Implementation of E-Government

Source : DeLone dan McLean (2003) 


\section{METHODOLOGY}

SAID Project Evaluation is implemented within the framework of learning theory. 'Action learning' originally came from Kolb's (1984) work on experiential learning and was developed by Schon (1983) to support the use of reflective practices toward professional development. Revans (1980) applies this insight into the organization and is one of the pioneers of action learning as a method for organizational development. The action learning framework for evaluation is particularly useful for the Pilot Project where project methods and / or structures may change during the evaluation in response to the participants' experience.

A key feature of 'action learning' is the assumption that programs and methods will continue to change in response to experience, both in small ways and sometimes because village governments reflect on their experiences and adjust future planning according to what they have learned. In most cases, these changes can not be anticipated prior to the start of the program. Moreover, village governments working on programs rarely record systematic changes and the reasons for their changes. Evaluations that capture these changes have the capacity to share learning achieved in one situation with others in the same situation.

One of the Project objectives and related evaluations is to develop and refine the program (process or formative evaluation) and ensure that it fits the objectives to be achieved. This study used a two-phase comparative data collection method, in which the baseline data were collected and compared with data collected at the end of the program (period of 6 months). Evaluation uses a qualitative methodology to investigate emerging problems in the field and aims to provide services in an interconnected environment. The qualitative approach allows evalua-tors to gain meaning and a deeper understanding of the problems faced in pilot project implementation. It also allows the evaluators to gain an in-depth understanding of the program's implementors of 'field' field weaknesses and how they are and do not meet the goals to be achieved. Furthermore, qualitative design provides insight into the results of SAID Implemetation program evaluation and helps uncover factors affecting the success of the program. Qualitative data collection methods include interviews, focus group discussions, participant observation, program document analysis and minutes of meetings. Further data were collected through interviews with beneficiaries ie villagers using SAID.

\section{RESULT}

\section{Implementation SAID}

The objective of the Village Information Administration System (SAID) is to establish an independent village in the data and information so that the village has data on the number of poor people who will be the basis for the government in formulating poverty programs, the introduction of village potentials, and marketing of village superior products. Bondowoso District has formed 10 villages that became the pilot project of Village Information Administration System (SAID) in Wringin and 
Cermee Subdistricts. the pilot program is then replicated by the Government of Bondowoso District by extending the implementation of Village Information Administration System in 62 villages throughout Bondowoso District. (Bondowosokab.go.id).

Table 1. Village data of SAID pilot project

\begin{tabular}{|c|l|l|}
\hline No & \multicolumn{1}{|c|}{ Distric } & \multicolumn{1}{|c|}{ Village } \\
\hline 1 & Wringin & Glingseran \\
2 & Wringin & Ambulu \\
3 & Wringin & Banyu putih \\
4 & Wringin & Bukor \\
5 & Cermee & Grujugan \\
6 & Cermee & Ramban Kulon \\
7 & Cermee & Ramban wetan \\
8 & Cermee & Suling wetan \\
9 & Cermee & Cermee \\
10 & Cermee & Bercak \\
\hline
\end{tabular}

Implementation of SAID in Bondowoso Regency is conducted through two stages. The first phase of the activity focuses on the making of regulations in the form of village regulations on the establishment of Village Information Implementation Committee (PPID). This first stage will be determined the organizational structure of the PPID. the responsible person is the Village Head and the implementer is the government who supervises several operators. Activities The first phase also socializes the introduction of SAID to the village community. The second stage is the verification of data to be included in the SAID program. The data is in the form of poverty data of the population derived from the data of the district and in the direct verivikasi so that will produce the data of the poor population.

In addition, SAID also serves to publicize village potentials into village superior products (one village one product). for example Wringin District Glingseran Village has the natural potential of a waterfall that is still not well managed. So that the potential of a tourism village into a superior product of glingseran village that will be managed properly. In addition, the superior product of Suling wetan Village, the potential of acid fruits that many people use the village into a candy tamarind.

Program of Village Information Administration System (SAID) as an effort to improve service to society with support of integrated information system need support facilities and infrastructure and human resources for the implementation of SAID Program optimally. Some conditions that must be fulfilled by village / kelurahan government to run SAID program are

1. The means used in the implementation of SAID, namely:

- Hall or Adequate Room

- Table 
- Computer

- LCD projector

- Bulletin boards or information boards

2. Infrastructure

- Electricity,

- Network / connection of information technology (internet), and

- Other necessary infrastructure

3. Human resources consisting of employees / staff / dispatchers in the village / kelurahan provided training / assistance of SAID application and guidance in providing excellent service to the community.

The Village Information Administration System is integrated with Bondowoso District website so that through the Village Information Administration System, Bondowoso District is able to integrate various government programs, especially programs based on village / kelurahan government in Bondowoso District.The Village Information Administration System provides convenience in governance, especially village governance. Various programs and activities of village governance can be integrated into one of these systems (SAID).all village government programs oriented to the interests of society can be done more effectively and efficiently.One form of government enforcement that becomes the scope in SAID is the implementation of services. The services that can be accessed through SAID are:

- Certificate handling (marriage, death, business establishment, Poverty, Resident Card)

- Document creation,

- A statement for various purposes,

- Poor statement, and

- Network data \& legal information

The acceleration in service delivery to the community is one of the focus of the SAID Program.SAID program which is integrated with service provision is expected to provide certainty, ease and generous fee in conducting service. Implementation of services carried out within the SAID Program covers almost all the provision of services to the community, whether it is administrative services or non-administrative services.SAID activities provide more value in the delivery of services to the community, there is a change in the process of service to digital services and integrated. The existence of integrated database support as a whole will provide convenience and certainty in the service process.

Integrated village / kelurahan integrated service delivery process supported through SAID can be seen from the following figure 


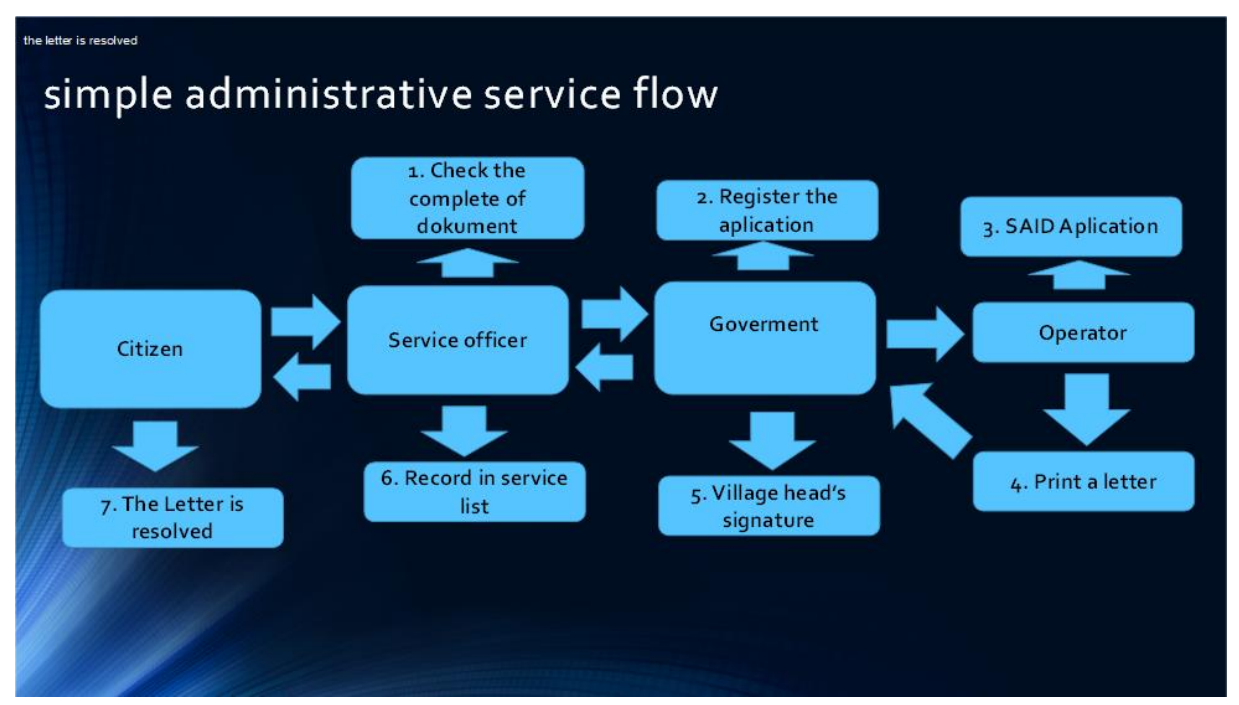

Figure 2. Simple administrative service flow

Sumber : General Guidance SAID

From Figure 2 can be seen the flow of simple administrative services:

1. The people come to the village hall to obtain administrative services such as KTP or other documents

2. The village government verifies the data with the population data and performs the applicant's data entry using the SAID application

3. After the application has been verified, the operator prints a letter and requests the signature of the village head.

Integrated information and data management enables quick and precise processes at various levels of government from the village / kelurahan, sub-district to district levels. Thus, there is a unity of data and data update, because it supported the process that allows the lowest level of government ie village / kelurahan become the source in input data. This reduces the duplication of data that is often a problem so far.

\section{Evaluation of SAID Program}

This evaluation is done after the implementation of pilot project phase 1 and 2 is completed. Data is taken 6 months after the program is completed. Evaluators see the impact of the pilot villages getting this program intervention. some performance indicators such as the acceleration of services to the village community, increased PAD villages through one village one product program.

\section{Integrated Services of Cerrmee Villagee}

The village of Cermee, one of the assisted villages of UMD Kompak, which is located on the border of Bondowoso and Situbondo regencies excels in integrated unit services. The village head of Cermee, Sutrisno, said that public services at the village level are increasingly efficient after the implementation of the Village Information Administration System (SAID), which is able to accommodate the administrative needs of citizens who can be managed at the village level. 
"Before the assistance to take care of administration takes longer, because it must be typed one by one. Now citizens simply bring ID cards, submit the request, then we just print and finish. the whole process takes only 5 minutes, "said Sutrisno"

This is because the mentoring conducted by the students includes the procedure of conducting surveys to collect various data from the villagers, train village officials to perform data validation and then put it into SAID. This is done to ensure that the information entered in SAID is valid and accountable.

Furthermore, Mr Sutrisno explained that although UMD activities have ended the data validation team continues to conduct surveys to accommodate all the villagers in the village. In addition, the implementation of the SAID community's trust on the performance of village government increased because the village open access to information widely. Through the official website of the village www.cermee.desa.id citizens can advocate criticism, suggestions and feedback and ask for information to the village site operators. One way to increase public confidence in village government is to publicly publish sources and use of village budgets in a form of infographic and published in various forms such as billboards and posters.

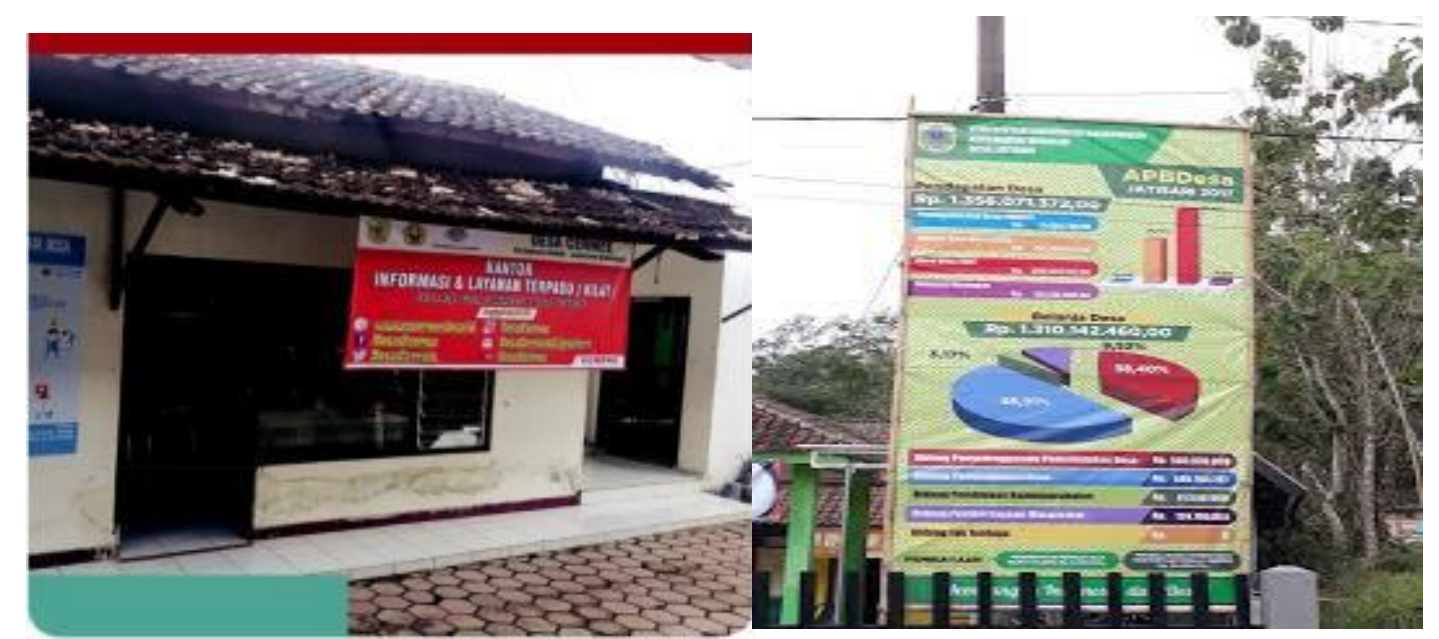

Figure 3 Integrated village service information office of mirrors and posters of the use of village funds

Cermee village is one of the winning villages with awarded Provincial Information Management and Documentation Award (PPID) Award in 2017. The award was given by the East Java Provincial Information Commission monitoring and evaluation of the East Java provincial and district / municipality offices of East Java on December 18, 2017. This award is given for the purpose of public bodies to improve the PPID and the quality of public information services. The new category given in 2017 is the village information disclosure.

\section{Excavation of Village Potential through one village one product}

Village Potential developed by Glingseran Village is the management and development of Desa Wisata. Glingseran village has the natural potential of a waterfall 
tourist attraction. The tourism potential was developed by the tourism conscious group (Pokdarwis). Waterfall attraction named sulaiman waterfall is very beautiful even the charm of this waterfall is also able to attract the attention of Bondowoso Tourism Office which later helped Pokdarwis promote Waterfall Sulaiman as a new tourist attraction in Bondowoso. In addition, there is also Taman Rengganis Tour which is said to be the location of the legendary bathing goddess Rengganis. Located in the middle of the river with views of green rice fields into a special attraction for tourists. The number of megalithic sites that depict the ancient civilizations in Bondowoso also become a historical tourist attraction offered Glingseran Village.

According to an interview with Glingseran Village Head Mr. Sulaedi explained "Many positive changes occurred in the village of Glingseran after the implementation of Universitas Membangun Desa (UMD), before our assistance has not realized that there is a lot of natural potential as a source of income for us, other impacts that arise after the development of tourism in the village is reduced unemployment.."

In addition to the tourist villages, Glingseran Village also optimizes the village potential to make superior products of local commodity-based villages such as snack production, virgin coconut oil and handicrafts. Villagers of Glingseran are committed to continue to develop their tourism potential by providing village development through the official website www.glingseran-bondowoso.desa.id.

Table 2 Implementation of SAID Activities

\begin{tabular}{|c|c|c|}
\hline SAID Information & Access & Information \\
\hline $\begin{array}{l}\text { Publication of } \\
\text { Village Potential, } \\
\text { Legal Product, } \\
\text { Village Profile, } \\
\text { Village Agenda } \\
\text { Information }\end{array}$ & 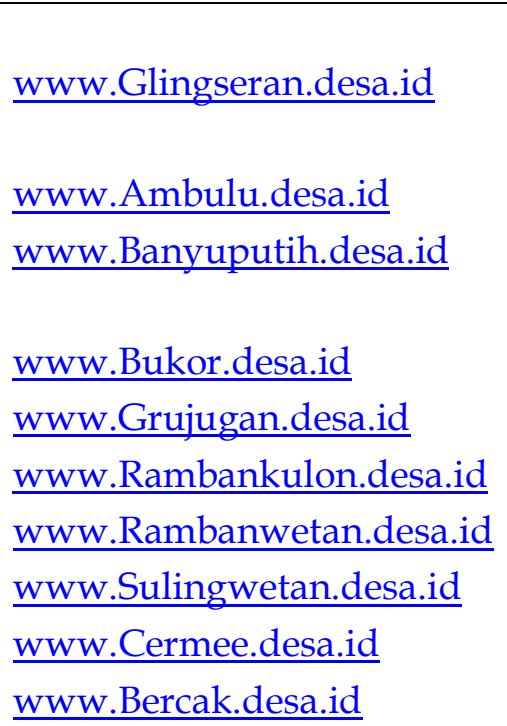 & $\begin{array}{c}\text { It is already running and } \\
\text { is used for publication of } \\
\text { village seed potential } \\
\text { Available } \\
\text { Already Running } \\
\text { Available } \\
\text { Available } \\
\text { Available } \\
\text { Available } \\
\text { Available } \\
\text { Available } \\
\text { Available }\end{array}$ \\
\hline
\end{tabular}

Source : Bondowoso.kab.go.id

\section{Findings}

Village Information Administration System Program is a new breakthrough in realizing Mandiri Village in data and information as well as service delivery to society based on village government. Seeing these conditions, it is necessary to evaluate the SAID program in Bondowoso District. Through this Evaluation not only provides a breakthrough overview of the SAID program but also provides a framework for the 
future development of SAID programs. several findings related to the results of research that affect the success of the program SAID

\section{Internet Network problem}

Provision of fiber optic internet network is a must for villages that will implement SAID program. But there are still some obstacles in the provision of internet networks, especially in remote villages that are not affordable to the internet. Some problems related to internet network are some villages in Kecamatan Cermee like Suling wetan Village difficulties with the availability of internet network due to very remote location of the village making it difficult for internet network availability.

\section{Low Human Resources Competence}

The availability of personnel or human resources is also a concern in the implementation of the SAID program in Bondowoso District. The needs of personnel in the implementation of SAID is the operator and the head of the hamlet / Kasun in charge of finding data. SAID operator becomes the key of success in its implementation, operator in charge of input data obtained from the villagers related to the number of poor people who have been validated, the excellent potential village that will be published in SAID as well as the agenda and activities Village.

Some problems occur in several villages such as Grujugan Village, Suling Kulon and Suling wetan. This can be known by inactivity of village website because the operator is not actively input data and news in SAID. Researchers conducted interviews with several village operators in Kecamatan Cermee. They explain that many other administrative tasks must be completed first before inputting the SAID data. In addition, the lack of competence and competence of village operators due to lack of mentoring and training to improve their competence.

SAID application requires training for every personnel, especially operators. With the introduction of new systems in the SAID application process it requires special training for operators to operate the system. Training becomes an important thing in the implementation of the program.

In terms of data and information integration, the SAID Application has not been integrated with various data on population assistance as well as data on health and education programs. So the village government can not map the priority of services to the more needy villagers. The integration of existing data is in the form of integration of population data, but not to various aid or data of health and education guarantee for each citizen.

\section{Lack of Support from Village Govement}

Support from the Local Government is also one of the supporting factors that affect the success of the University Building Village Program through SAID. The program will succeed if the village head, village apparatus and village community have the willingness, ability and high motivation to receive and apply the program. 
With the birth of Village Law No. 6 of 2014, the Village has the authority to regulate its own territory. Village Funds that the Government disburses to the village in accordance with the government's vision to build from the periphery / village. The implication of this is that the village head has the authority to use the Village Fund in accordance with established rules in accordance with village needs. As a result of this matter the position of the head of the village became the most contested position by the villagers so that now there are many conflicts in the village to compete for the position of village head.

This phenomenon occurred in several villages in Cermee sub-district such as Desa Ramban Kulon and Ramban wetan. The village head is in conflict with the community and other village apparatus for the position of the village head. The impact of the village head and village apparatus did not prioritize the UMD program in the village. The low support from the Village Government caused the UMD program to be not maximally implemented.

\section{Inadequate facilities dan infrastruktur}

Facilities and Infrastructure are also important to meet in this program. facilities such as special rooms for integrated service information equipped with computer and operator desk. Observations by field researchers see that inadequate facilities and infrastructure such as the limitations of village halls in providing information and service space and the availability of computers that are required to run SAID applications.

\section{CONCLUTION AND RECOMMENDATIONS}

Based on the explanation and analysis on the evaluation of SAID in Bondowoso District, it Can be concluded that the use of SAID in bondowoso district can realize independent villages in the data and information and can improve the quality of service to the community for the better. The village has a data base that became the reference of district government in making policy of empowerment and make service to society become faster, easier and cheaper. However, there are some problems in the implementation such as remote villages that still have internet network, low competence of human resources in the village, low support from village government and lack of facilities and infrastructure.

Researcher's recommendation based on analysis of research that has been described is the role of government of Bondowoso Regency in providing fiber optic internet network to every village that run SAID Application. Bondowoso District Government should facilitate cooperation between village government with fiber optic internet service provider or PT Telkom Indonesia. Some villages that have not reached the fiber optic internet network began to build access network with the installation of fiber optic internet network to the village that will implement SAID program. The government of Bondowoso District provides guidance and training of SAID Applications and programming using computers primarily for operators and rural 
apparatus. in addition, support and high motivation from the village government is required to implement, use and develop SAID applications and support facilities and infrastructure from the district government to village governments with minimal facilities and infrastructure.

\section{REFERENCES}

Anthopoulos, L., Reddick, C. G., Giannakidou, I., \& Mavridis, N. (2016). Why egovernment projects fail? An analysis of the Healthcare.gov website. Governement Information Quarterly, 161-173.

DeLone, W. H., \& McLean, E. R. (2013). The DeLone and McLean Model of Information Systems Success: A Ten-Year Update. Jornal of management Information System, 9-30.

Fang, Zhang., (2002). E-Government in Digital Era : Concept, Practice, and Development, International Journal of The Computer, The Internet and Management, $1-22$

Kolb, D. A. (1984). Experiential learning, experience as the source of learning and devel-opment. Prentice Hall: Englewood Cliffs, New Jersey.

Larson \& Grounlund. (2014). Sustainable e-Goverment. Governement Information Quarterly, 623-642.

Revans, R. W. (1980). Action learning: New techniques for management. London: Blond and Biggs.

Schon, D. A. (1983). The reflective practitioner: How professionals think in action. New York: Basic Books.

Yildis, M. (2007). E-government research : Re viewing the literature, and ways forward. Governement Information Quarterly, 646-665. 